\title{
BIOFEEDBACK TRAINING AND TENSION-TYPE HEADACHE
}

\author{
Ana Šečić, Timon Cvjetičanin and Vanja Bašić Kes \\ ${ }^{1}$ Clinical Department of Neurology, Sestre milosrdnice University Hospital Center, Zagreb, Croatia
}

\begin{abstract}
SUMMARY - Biofeedback is a training method, which connects physiological and psychological processes in a person for the purposes of improving his/her physical, emotional, mental and spiritual health. In biofeedback treatment, an active role of the patient is stressed for him/her to be able to actively control the physiological and emotional processes. The aim of biofeedback is to improve the conscious control of the individual's involuntary physiological activity. Research has shown that biofeedback, either applied alone or in combination with other behavioral therapies (techniques), is an effective treatment for various medical and psychological disorders, from headache and hypertension to temporomandibular and attention deficit disorders. More than $90 \%$ of adults experience headache once a year, which makes headache one of the most common symptoms and diagnoses in medicine. Tension-type headaches occur in at least $40 \%$ of the population and their impact on the health insurance costs and diminished productivity is significant. Studies have shown that clinical biofeedback training is effective in treating headaches. Moreover, the authors stress the need for additional research and further development of methodology for this kind of research.
\end{abstract}

Key words: Biofeedback, psychology; Tension-type headache - therapy

\section{Introduction}

The term "biofeedback" first appeared in 1969, when it was used to describe certain army laboratory research in the 1940s, in which patients were learning how to modify their heart rate, blood pressure, and other physiological functions, which are not subject to voluntary control ${ }^{1}$. The Association for Applied Psychophysiology and Biofeedback (AAPB) stated that "this evolution has been driven by years of scientific research demonstrating that the mind and body are connected, and that people can be taught to harness the power of this connection to change physical activity and improve health and function" ${ }^{2}$. Over years,

Correspondence to: Ana Šečic, $M S$, Clinical Department of Neurology, Sestre milosrdnice University Hospital Center, Vinogradska c. 29, HR-10000, Zagreb, Croatia

E-mail: anasecic@gmail.com

Received March 31, 2014, accepted September 3, 2015 the concept of "biofeedback" has replaced other terms which had been in use before, such as "external psychophysiological feedback", "physiological feedback" and "augmented proprioception" 3

As defined by the AAPB, "Biofeedback is a process that enables an individual to learn how to change physiological activity for the purposes of improving health and performance. Precise instruments measure physiological activity such as brainwaves, heart function, breathing, muscle activity, and skin temperature. These instruments rapidly and accurately "feed back" information to the user. The presentation of this information - often in conjunction with changes in thinking, emotions, and behavior - supports desired physiological changes. Over time, these changes can endure without continued use of an instrument" 2 . In the biofeedback method, patient's active role is stressed, as he/she takes an active part in controlling the physiological and emotional processes. In addition to this, the application of biofeedback is considered to 
be training rather than treatment, since the concept of treatment can imply the passive role of the patient ${ }^{4}$.

Biofeedback training is based on two learning models, each of them providing a feedback the aim of which is to have an impact on a certain process. The first learning model refers to instrumental (operative) and feedback learning and is based on consequences, that is, on achieving the conditioned reaction; it is connected to a type of training in patients with physical diseases ${ }^{5}$. The second learning model, psychophysiological psychotherapy, includes the element of psychotherapy "in order to make patients aware of how the stress in their lives has an effect on physiology". This model includes psychophysiological assessment and psychological evaluation in order to determine the thought and behavior patterns that contribute to the patient's physiological vulnerability ${ }^{6}$.

Biofeedback training can be carried out individually or in group. A typical training program consists of 10 to 20 sessions, which last 20 to 60 minutes each, and the training is usually held in an environment which is peaceful and pleasant for the patient. During the biofeedback training, by employing various devices (sensors), it is possible to track one or more physiological parameters simultaneously and transform physiological data into a feedback that the patient can understand and which he/she can use to supervise the physiological processes ${ }^{1}$.

Studies have shown that biofeedback, either applied alone or in combination with other behavioral therapies (techniques), is effective in treating different medical and psychological disorders, from headache and hypertension to temporomandibular and attention deficit disorders. Biofeedback has developed early on into a research-based approach, developing directly from laboratory research of psychophysiology and behavioral therapy. Biofeedback has found its application in psychology, neurology, sports, physical medicine and other somatotherapy, and it has been used for treating various kinds of disorders, for many of them having become a standard manner of training ${ }^{7-9}$.

\section{Tension-Type Headache and Biofeedback Training}

More than $90 \%$ of adults suffer from headache once a year, and this fact makes headache one of the most common symptoms and diagnoses in medicine. Tension-type headaches make up about $75 \%-90 \%$ of all headaches ${ }^{10,11}$. They are characterized by pressing/tightening (non-pulsating) quality, lasting from 30 minutes to 7 days and having at least two of the following characteristics: bilateral location, mild or moderate intensity, not aggravated by routine physical activity such as walking or climbing stairs, and no nausea or vomiting, and no more than one of photophobia or phonophobia $^{12-14}$. Tension headaches contain psychogenic and somatic etiologic factors in terms of bodily response to emotional stress ${ }^{15}$. Many experts believe that tension of the head, neck and shoulder muscles causes stress and tension headaches. Recent findings on the nociceptive system disclose that the pain which occurs in tension headaches has a muscular origin. However, some scientists disagree on this, as electromyography (EMG) often fails to record increase in muscle tone during rest in patients with tension headache ${ }^{11}$.

Tension-type headaches occur in at least $40 \%$ of the population and their impact on the medical care utilization and diminished productivity is significant. Drugs remain the basic therapy for all headache types and they are being prescribed and bought in great quantities. The side effects occur frequently and may sometimes be life threatening. Drugs also contribute to the decrease in productivity in those suffering from headache ${ }^{16}$.

In 1970, Budzynski et al. presented the use of EMG biofeedback in treating tension-type headache ${ }^{17}$. Since then, many studies have shown that EMG biofeedback training, when applied alone or in combination with relaxation techniques, decreases tension-type headaches by $40 \%-60 \%$. EMG biofeedback induces the feeling of relaxation in the entire body by using the feedback system in a way that the patient via headphones follows the sound signals the frequency of which is proportional to the EMG activity of the observed muscle (in headaches, it is most often frontal muscle). The authors note that the patient should be able to accomplish the same effects after undergoing the biofeedback application program, even after one is separated from the biofeedback system, and finally one should be able to decrease the frequency and seriousness of his/her headaches ${ }^{16}$.

Most of the original researches in this field were conducted by measuring thermoregulation of the sub- 
ject's arms during controlled exercise of relaxing and while the patient was receiving feedback in real time and exercising his/her conscious control. A metaanalysis of over 50 studies on biofeedback has shown that it is a more effective modality than placebo or relaxation therapy. Biofeedback does not only affect the frequency of headache, but it also affects muscle tension, analgesic use, mood regulation and self-efficacy evaluation. Biofeedback can be combined with other modalities, and its combination with relaxation training can be most effective. In one EMG biofeedback training study, students that received the high efficiency feedback showed much better improvement in terms of reduced headache frequency than those having received feedback of a more moderate effect ${ }^{18}$.

Nestoriuc et al. analyzed the results of 94 studies, according to which the most significant effects of biofeedback were recorded in migraines and tension-type headaches. Moreover, stable effects of treatment were also noted during the mean observational period of 14 months. The main criterion of assessment in these studies was headache frequency, and according to this criterion, the greatest improvement was recorded. Other improvements were recorded for the following variables: self-sufficiency, anxiety, depressions and medication intake. In tension-type headache, the decrease in muscle tension in the areas of pain (EMG feedback) was recorded. Furthermore, biofeedback proved to be more effective than placebo and relaxation therapies ${ }^{19}$.

Results of a research conducted on 43 students suffering from recurring tension headaches showed the importance of feedback for the success of EMG biofeedback training. Students were divided into two groups, both of which were getting information that did not show the real result of the training. In the first group, results were presented as considerably more successful than the real ones, whereas in the second group results were presented as lower in success than the real ones. Despite the real changes in EMG activity, students in the first group showed a much greater decrease of headaches than students in the second group. These results suggest that the effectiveness of EMG biofeedback training in case of tension headache can be mediated by cognitive changes induced by the feedback effect ${ }^{20}$.

Mullally et al. conducted a study the aim of which was to assess the effectiveness of biofeedback in de- creasing the frequency and severity of migraine and tension headaches. In total, 64 subjects participated in the research, all of them having experienced migraines for more than one year. Electrodes were placed on the frontal muscle and trapezius muscle. The participants were divided into two groups. Group 1 consisted of 33 subjects who used biofeedback training in combination with the relaxation technique ${ }^{16}$. Group 2 consisted of 31 participants who were undergoing the relaxation techniques without taking part in the biofeedback training. Over time, improvement was observed in both groups. After three months, reduced headache intensity was reported by $35 \%$ of group 1 patients (biofeedback training) and $48 \%$ of group 2 patients (relaxation technique). After six months, 57\% of group 1 subjects undergoing biofeedback reported fewer headaches, while in group 2 the respective figure was $52 \%$. The value of this study also lies in patient assessment, since the patients reported improvement after completion of the biofeedback training, which certainly should not be neglected. Accordingly, an individual approach to each person is needed ${ }^{16}$.

The impact of behavioral treatment (such as relaxation, biofeedback and cognitive-behavioral therapy) on chronic tension-type headache in adults was investigated by Verhagen et al. Data were analyzed by qualitative analysis. The authors claim that the most promising treatment is a combination of the relaxation techniques and EMG biofeedback. Moreover, the authors stress the need for further studies which should employ better research methodology ${ }^{21}$.

Arndorfer and Allen investigated the application of temperature training biofeedback in a sample of five children with tension headaches. After 6 months of hand-warming training, the headaches disappeared in $80 \%$ of the sample ${ }^{22}$.

Labbe also employed skin temperature biofeedback together with the application of autogenic training; based on a sample consisting of 30 children with migraines, divided into three groups, he compared the groups, of which only the first group underwent biofeedback and autogenic training, the second group underwent autogenic training alone, whereas the third group was not included in any kind of training or treatment. Results showed significant improvement in $80 \%$ of the first group children and $50 \%$ in the second group children, while there was no improvement in the third group ${ }^{23}$. 


\section{Conclusion}

Biofeedback therapy has a wide application because the patient acquires a set of skills which boost the body's natural tendency to return to healthy homeostasis. Studies have shown that the biofeedback training is effective in treating various medical conditions and its use is recommended in addition to other modalities (such as relaxation). Using biofeedback is also recommended in the treatment of headaches, as demonstrated in a number of studies. Biofeedback is considered to be training rather than treatment, since the patient takes an active role in controlling the physiological and emotional processes (and the concept of treatment implies patient passiveness). All this shows why biofeedback has found application in psychology, neurology, sports, physical medicine and other somatotherapy, and has been used for treating various kinds of disorders.

It is necessary to further study the mechanisms by which the biofeedback operates. Better research protocols will also contribute to more accurate conclusions based on the results, as well as to facilitate comparison.

\section{References}

1. McKee MG. Biofeedback: an overview in the context of heart-brain medicine. Cleve Clin J Med. 2008;75:S31-4. DOI:10.3949/ccjm.75.Suppl_2.S31

2. The Association for Applied Psychophysiology and Biofeedback - AAPB URL: http://www.aapb.org/i4a/pages/index. cfm?pageid $=1$

3. Schwartz MS, et al. Biofeedback: A Practitioner's Guide (Second Edition). New York: The Guilford Press, 2005.

4. Myers JE, Young S. Brain wave biofeedback: benefits of integrating neurofeedback in counseling. J Counsel Dev. 2012;90(1):20-8. DOI: 10.1111/j.1556-6676.2012.00003.x

5. Basmajian JV. Biofeedback: Principles and Practice for Clinicians. Baltimore: Williams \& Wilkins, 1989.

6. Frank LD, Khorshid L, Kiffer JF, Moravec CS, McKee MG. Biofeedback in medicine: who, when, why and how? Mental Health Fam Med. 2010;7:85-91. DOI: 10.1002/9780470935538.app4

7. Yucha C, Gilbert C. Evidence-Based Practice in Biofeedback and Neurofeedback. Association for Applied Psychophysiology \& Biofeedback, First Edition, 2004.

8. Moss D, Gunkelman J. Task Force report on methodology and empirically supported treatments: introduction and summary. Appl Psychophysiol Biofeedback. 2002;27(4):261-2.
9. Peper E, Shaffer F. Biofeedback history: an alternative view. Biofeedback Clin J. 2010;38(4):142-7. DOI: http://dx.doi. org/10.5298/1081-5937-38.4.03

10. Trkanjec Z. Headache tenzijskog tipa. Suvremeni pristup dijagnostici i liječenju glavobolje. Medix. 2005;59:70-4. (in Croatian)

11. Buljan D. Psihološki čimbenici i glavobolja (psihogena glavobolja). Suvremeni pristup dijagnostici i liječenju glavobolje. Medix. 2005;59:92-6. (in Croatian)

12. Demarin V, Trkanjec Z. Neurologija. Medicinska naklada, Zagreb; 2008. (in Croatian)

13. Demarin V, Bašić Kes V, et al. Glavobolja i druga bolna stanja. Medicinska naklada, Zagreb; 2011. (in Croatian)

14. The International Classification of Headache Disorders. URL: http://ihs-classification.org/en/

15. Poeck K. Neurologija. Školska knjiga, Zagreb; 2000. (in Croatian)

16. Mullally W, Hall K, Goldstein R. Efficacy of biofeedback in the treatment of migraine and tension type headaches. Pain Physician. 2009;12:1005-11.

17. Budzynski T, Stoyva J, Adler C. Feedback-induced relaxation: application to tension headache. J Behav Ther Exp Psychiatry. 1970;1(3):205-11. DOI:10.1001/archpsyc.1980. 01780210024002.

18. Rosen NL. Psychological Issues in the Evaluation and Treatment of Tension-Type Headache. Springer Science and Business Media, New York; 2012. DOI:http://dx.doi:10.1007/ s11916-012-0301-z.

19. Nestoriuc Y, Martin A, Rief W, Andrasik F. Biofeedback treatment for headache disorders: a comprehensive efficacy review. Appl Psychophysiol Biofeedback. 2008;33:125-40. DOI:http://dx.doi.org/10.1007/s10484-008-9060-3.

20. Rains JC. Change Mechanisms in EMG Biofeedback Training: Cognitive Changes Underlying Improvements in Tension Headache. Journal compilation, American Headache Society. 2008;48:735-7. DOI:http://dx.doi.org/ 10.1111/j.1526-4610 .2008.01119_1.x

21. Verhagen AP, Damen L, Berger MY, Passchier J, Koes BW. Behavioral treatments of chronic tension-type headache in adults: are they beneficial? CNS Neurosci Ther. 2009;15:183-205. DOI:http://dx.doi.org/ 10.1111/j.1755-5949. 2009.00077.x

22. Arndorfer RE, Allen KD. Extending the efficacy of a thermal biofeedback treatment package to the management of tension-type headache in children. Headache. 2001;41:183-92. DOI:http://dx.doi.org/10.1046/j.1526-4610 .2001.111006183.x

23. Labbé EE. Treatment of childhood migraine with autogenetic training and skin temperature biofeedback: a component analysis. Headache. 1995;35(1):10-3. DOI: http://dx.doi. org/10.1111/j.1526-4610.1995.hed3501010.x. 
Sažetak

TRENING BIOLOŠKOM POVRATNOM VEZOM (BIOFEEDBACK) I GLAVOBOLJA TENZIJSKOG TIPA

\section{A. Šečic, T. Cujetičanin i V. Bašic Kes}

Trening biološkom povratnom vezom (biofeedback) je metoda treninga koja povezuje fiziološke i psihološke procese kod čovjeka u svrhu poboljšanja fizičkog, emocionalnog, mentalnog i duhovnog zdravlja. Kod biofeedbacka naglašena je aktivna uloga bolesnika u smislu njegove uključenosti u kontrolu fizioloških i emocionalnih procesa. Cilj biofeedbacka je poboljšati svjesnu kontrolu nesvjesnih fizioloških aktivnosti pojedinca. Istraživanja pokazuju da je biofeedback, sam ili u kombinaciji s drugim bihevioralnim terapijama (tehnikama), učinkovit u liječenju različitih medicinskih i psiholoških poremećaja, od glavobolje i hipertenzije do temporomandibularnih poremećaja i poremećaja pažnje. Više od $90 \%$ odraslih osoba jedanput na godinu ima glavobolju, stoga taj podatak glavobolju čini jednim od najčešćih simptoma i dijagnoza u medicini. Glavobolje tenzijskog tipa pojavljuju se u najmanje $40 \%$ populacije i njihov je učinak na troškove zdravstvene zaštite i smanjenje produktivnosti značajan. Istraživanja su pokazala da je klinički biofeedback trening učinkovit u liječenju glavobolja. Također, autori naglašavaju potrebu za daljnjim istraživanjima i daljnjim razvojem metodologije ove vrste istraživanja.

Ključne riječi: Biološka povratna veza, psibologija; Tenzijska glavobolja-terapija 